\title{
Risk factors for ischemic stroke and transient ischemic attack in patients under age 50
}

\author{
A. W. M. Janssen • F. E. de Leeuw • \\ M. C. H. Janssen
}

Published online: 9 June 2010

(C) The Author(s) 2010. This article is published with open access at Springerlink.com

\begin{abstract}
To analyze risk factors for ischemic stroke and transient ischemic attack (TIA) in young adults under the age of 50. To make recommendations for additional research and practical consequences. From 97 patients with ischemic stroke or TIA under the age of 50, classical cardiovascular risk factors, coagulation disorders, history of migraine, use of oral contraceptives, cardiac abnormalities on ECG and echocardiography, and the results of duplex ultrasound were retrospectively analyzed. Literature was reviewed and compared to the results. $56.4 \%$ of the patients had hypertension, $12.1 \%$ increased total cholesterol, $20 \%$ hypertriglyceridemia, $31.5 \%$ an increased LDL-level, $32.6 \%$ a decreased HDL-level and $7.2 \%$ a disturbed glucose tolerance. Thrombophilia investigation was abnormal in 21 patients and auto-immune serology was abnormal in 15 patients. Ten of these patients were already known with a systemic disease associated with an increased risk for ischemic stroke (i.e. systemic lupus erythematosus). The ECG was abnormal in $16.7 \%$ of the cases, the echocardiography in $12.1 \%$ and duplex ultrasound of the carotid arteries was in $31.8 \%$ of the cases abnormal. Conventional cardiovascular risk factors are not only important in patients over the age of 50 with ischemic stroke or TIA, but also in this younger population under the age of 50 . Thrombophilia investigation and/ or autoimmune serology should be
\end{abstract}

A. W. M. Janssen · M. C. H. Janssen ( $ه)$

Department of Internal Medicine, Radboud University Nijmegen

Medical Centre, P.O. Box 9101, 6500 HB Nijmegen,

The Netherlands

e-mail: m.janssen@aig.umcn.nl

F. E. de Leeuw

Donders Institute for Brain, Cognition and Behaviour, Centre for Neuroscience, Department of Neurology, Radboud University

Nijmegen Medical Centre, Nijmegen, The Netherlands restricted to patients without conventional cardiovascular risk factors and a history or other clinical symptoms associated with hypercoagulability and/ or autoimmune diseases.

Keywords Young stroke - Thrombophilia ·

Cardiovascular risk factors · Echocardiography .

Duplex ultrasound

\section{Introduction}

Stroke is the most important cause of disablement in the western world. In the Netherlands it is the third cause of lost Disability-Adjusted Life-Years (DALY's) — after coronary disease and anxiety diseases [1]. About $10 \%$ of all strokes occur in patients $<50$ years of age. Risk factors in these young stroke patients differ from those found in older people [2]. Etiology of ischemic stroke in young adults remains uncertain $[3,4]$ and multiple factors have been reported as risk factors like traditional vascular risk factors [5, 6], thrombophilia [6-18], migraine [6, 19-22], auto-immune disorders [23-27] and cardiac anomalies [6, 28-35].

The present study aimed to determine classical risk factors and prevalence of thrombophilic risk factors and autoimmune serology in patients under the age of 50 with transient ischemic attack (TIA) or ischemic stroke. Furthermore the practical consequences of these investigations are discussed.

\section{Patients and methods}

Population

This retrospective study included a series of 97 patients under the age of 50, diagnosed with ischemic stroke or TIA 
(after history taking, physical examination and brain imaging studies), admitted to the neurology department of the Radboud University Nijmegen Medical Centre between September 2004 and January 2008. Medical records of these patients were reviewed. The data of these patients were retrospectively analyzed and compared with literature.

\section{Risk factors}

The following data were collected: gender, age, type of event, smoking, use of oral contraceptives, cardiovascular history (previous stroke or TIA, myocardial infarction, venous thromboembolism, hypertension, hypercholesterolemia or pre-eclampsia/HELLP-syndrome/spontaneous abortion), positive family history for cardiovascular disease (first-degree female family members $<65$ years and firstdegree male family members $<55$ years), migraine, diabetes, blood pressure (hypertension was classified as a blood pressure $>140 / 90 \mathrm{mmHg}$ or treatment with antihypertensive medication) ECG, echocardiography and duplex ultrasound of the extra cranial arteries.

\section{Cardiac imaging}

ECGs were analyzed. Almost all patients underwent twodimensional transthoracic echocardiography (TTE). Potential cardiac sources of embolism were: patent foramen ovale (PFO), atrial septal aneurysm (ASA), mitral stenosis, mitral insufficiency, atrial fibrillation, endured myocardial infarction, endocarditis, intracardial thrombus, atrial myxoma, prosthetic valve, non-ischemic dilating cardiomyopathy and left ventricular akinesis.

\section{Carotid ultrasound}

The results of duplex ultrasound of the extra cranial arteries were divided in four categories: normal, non-significant atherosclerotic changes (e.g. slightly increased intima media thickness without significant haemodynamic changes), significant atherosclerotic changes (i.e. vascular stenosis with luminal reduction $\geq 50 \%$ ) and other significant vascular damage (i.e. dissection).

\section{Laboratory assays}

The following laboratory data were evaluated: total cholesterol, triglycerides, LDL cholesterol, HDL cholesterol, glucose, protein $\mathrm{C}$, free protein $\mathrm{S}$ and antithrombin activity, factor $\mathrm{V}$ Leiden, factor II mutation (prothrombin G202010A mutation), homocysteine, lupus anticoagulant and anticardiolipin antibodies (IgG and $\operatorname{IgM}$ ), antinuclear antibodies (ANA), anti-neutrophil cytoplasmic antibodies (ANCA).

Reference values were $70-150 \%$ for protein $\mathrm{C}$, $65-130 \%$ and $55-115 \%$ respectively for men and women for free protein $\mathrm{S},>80 \%$ for antithrombin, $<15 \mu \mathrm{mol} / \mathrm{l}$ for homocysteine, $<6.5 \mathrm{mmol} / \mathrm{l}$ for total cholesterol, $<2.00$ $\mathrm{mmol} / \mathrm{l}$ for triglycerides, $>1.10 \mathrm{mmol} / \mathrm{l}$ for $\mathrm{HDL}$ and $<3.50 \mathrm{mmol} / 1$ for LDL cholesterol. The normal values for fasting blood sugar and non-fasting blood sugar were $<6.1$ and $<7.8 \mathrm{mmol} / \mathrm{l}$.

\section{Results}

\section{Cardiovascular risk factors}

Of the 97 patients, 49 had an ischemic stroke and 48 had a TIA. Mean age of the study population was $41.3 \pm 7.7$ years (range 17.04-49.97 years) and 57 (58.8\%) were females. The presence of the classical atherosclerotic risk factors are presented in Table 1. The most common cardiovascular risk factor was hypertension (56.4\%), followed by a positive cardiovascular medical history (47.9\%), a positive family history (44.4\%) and smoking (40.0\%). $32.6 \%$ of the patients had a decreased HDL-level. LDL was elevated in $31.5 \% .73 .2 \%$ of the patients had two or more cardiovascular risk factors. Only $8.5 \%$ had no cardiovascular risk factor.

\section{Cardiac imaging}

ECGs showed hardly any abnormalities (Table 2). Disturbed repolarisation was the most common abnormality (7.7\%). In our population five patients had a PFO (6.4\%) and also five patients $(6.4 \%)$ had mitral insufficiency (Table 2). One patient had a congenital anomaly consisting of a pulmonary artery aplasia and hypoplastic right ventricle.

\section{Gynaecological history}

$14 \%$ (8) of the women had a history of one or two spontaneous abortions. Three of them had a history of preeclampsia. $42.9 \%$ of the women used oral contraceptives (Table 1).

Migraine

In our study group, $20.2 \%$ of the patients had a history of migraine. The combination of migraine and the use of oral contraception occurred in $9.3 \%$, the combination of migraine and $\mathrm{PFO}$ in $3.1 \%$. Sixty percentage of the patients with PFO were familiar with migraine. 
Table 1 Demographic data and risk factors

\begin{tabular}{|c|c|c|c|}
\hline & All $(n=97)$ & Males & Females \\
\hline \multicolumn{4}{|l|}{ Nonmodifiable risk factors } \\
\hline Age, y & $41.3 \pm 7.7(17.04-49.97)^{\mathrm{a}}$ & $43.0 \pm 7.2(17.04-49.97)^{\mathrm{a}}$ & $40.1 \pm 7.8(19.25-49.89)^{\mathrm{a}}$ \\
\hline Gender & - & $40(41.2)$ & $57(58.8)$ \\
\hline Ischemic stroke $(\mathrm{N})$ & $49(50.5)$ & $19(38.8)$ & $30(61.2)$ \\
\hline \multirow[t]{2}{*}{ TIA (N) } & $48(49.5)$ & $21(43.8)$ & $27(56.2)$ \\
\hline & & Number scored (\%) & Positive result $(\%)$ \\
\hline Cardiovascular family history & - & $90(92.8)$ & $40(44.4)$ \\
\hline \multicolumn{4}{|c|}{ Well-documented and modifiable risk factors } \\
\hline Cardiovascular history & - & $94(96.9)$ & $45(47.9)$ \\
\hline Cigarette smoking & - & $95(97.9)$ & $38(40)$ \\
\hline Hypertension & - & $94(96.9)$ & $53(56.4)$ \\
\hline Hypercholesterolemia & - & $91(93.8)$ & $11(12.1)$ \\
\hline Hypertriglyceridemia & - & $90(92.8)$ & $18(20.0)$ \\
\hline Increased LDL & - & $89(91.8)$ & $28(31.5)$ \\
\hline Decreased HDL & - & $89(91.8)$ & $29(32.6)$ \\
\hline Glucose $>7.8$ & - & $97(100)$ & $7(7.2)$ \\
\hline Glucose $>6.1$ & - & $97(100)$ & $19(19.6)$ \\
\hline Cardiovascular risk factors ${ }^{\mathrm{b}}$ & - & - & - \\
\hline 0 & - & $82(84.5)$ & $7(8.5)$ \\
\hline 1 & - & $82(84.5)$ & $15(18.3)$ \\
\hline 2 & - & $82(84.5)$ & $21(25.6)$ \\
\hline 3 & - & $82(84.5)$ & $16(19.5)$ \\
\hline 4 & - & $82(84.5)$ & $14(17.1)$ \\
\hline 5 & - & $82(84.5)$ & $8(9.8)$ \\
\hline 6 & - & $82(84.5)$ & $1(1.2)$ \\
\hline \multicolumn{4}{|c|}{ Less well-documented, potentially modifiable risk factors } \\
\hline History of migraine & - & $94(96.9)$ & $19(20.2)$ \\
\hline Oral contraceptive use & - & $96(99.0) / 56(98.2)$ & $24(25.0) / 24(42.9)$ \\
\hline
\end{tabular}

Data are expressed as mean \pm SD or $n(\%)$

$T I A$ transient ischemic attack; $L D L$ low-density lipoprotein; $H D L$ high-density lipoprotein

a Range

b Smoking, hypertension, high glucose level, high total cholesterol, high triglycerides, high LDL, low HDL, significant changes of duplex ultrasound, positive cardiovascular history

\section{Carotid ultrasound}

The results of the duplex ultrasound are shown in Table 2 . $20 \%$ of the patients had non-significant and $11.8 \%$ had significant atherosclerotic changes or dissection.

Thrombophilic and autoimmune investigations

Not all patients had a complete trombophilia and autoimmune work-up (Table 2). Increased homocysteine was present in $13.6 \%$. The two patients with mildly decreased protein $\mathrm{C}$ and the patient with decreased protein $\mathrm{S}$ used oral contraceptives. The auto-immune research resulted in a positive ANA in $8.1 \%$ and a positive ANCA in $7.4 \%$.
Studying the history of the patients, we found that a disorder associated with increased blood coagulation and/or vasculitis in combination with ischemic stroke was present in 17 patients (Table 3). This group represented 1/2 decreased protein $\mathrm{C}, 1 / 1$ decreased antithrombin, 1/1 positive lupus anticoagulant, $3 / 6 \mathrm{FVL}, 1 / 3$ factor II mutation, 5/7 positive ANA and 2/6 positive ANCA (divided over 10 patients). Two patients in Table 2 were not screened for trombophilia and auto-immune disorders.

Some patients showed more than one abnormality. One patient known with SLE had a positive ANA and lupus anticoagulant; one patient with SLE presented with positive ANA, FVL and factor II mutation; one patient known with M. Crohn had a decreased protein $\mathrm{C}$ and antithrombin; a patient with 
Table 2 Etiology of ischemic stroke/TIA

\begin{tabular}{|c|c|}
\hline & Positive result $(\%)$ \\
\hline \multicolumn{2}{|l|}{ Echocardiography $(n=78)$} \\
\hline PFO & $5(6.4)$ \\
\hline ASA & $1(1.3)$ \\
\hline Mitralis stenosis & 0 \\
\hline Mitralis insufficience & $5(6.4)$ \\
\hline Atrial fibrilation & 0 \\
\hline Endured myocardial infarction & $2(2.6)$ \\
\hline Endocarditis & 0 \\
\hline Intracardial thrombus & 0 \\
\hline Atrial myxoma & 0 \\
\hline Prosthetic valve & $2(2.6)$ \\
\hline Non-ischemic dilating cardiomyopathy & $1(1.3)$ \\
\hline Left ventricular akinesis & $2(2.6)$ \\
\hline Congenital cardiac anomaly & $1(1.3)$ \\
\hline $\mathrm{ECG}(n=91)$ & - \\
\hline Sinus rhythm & $91(100)$ \\
\hline Atrial fibrillation & 0 \\
\hline Endured myocardial infarction & 0 \\
\hline Disturbed repolarisation & $7(7.7)$ \\
\hline Left ventricle hypertrophy & $1(1.1)$ \\
\hline Left bundle-branch block & $1(1.1)$ \\
\hline Congenital cardiac anomaly & $2(2.2)$ \\
\hline Thrombophilia & - \\
\hline Protein $\mathrm{C}<70(n=82)$ & $2(2.4)$ \\
\hline Free Protein S: $\widehat{o}<65 ;$; $+<55(n=82)$ & $1(1.2)$ \\
\hline Antithrombin $<80(n=85)$ & $1(1.2)$ \\
\hline Factor V Leiden $^{\mathrm{a}}(n=85)$ & $6(7.1)$ \\
\hline Factor II mutation $^{\mathrm{a}}(n=84)$ & $3(3.6)$ \\
\hline Homocysteine $>15(n=81)$ & $11(13.6)$ \\
\hline Auto-immune & - \\
\hline Lupus anticoagulant $(n=85)$ & $1(1.2)$ \\
\hline Anticardiolipine $\operatorname{IgG}(n=83)$ & $2(2.4)$ \\
\hline Anticardiolipine $\operatorname{IgM}(n=83)$ & $1(1.2)$ \\
\hline ANA $(n=86)$ & $7(8.1)$ \\
\hline $\operatorname{ANCA}(n=81)$ & $6(7.4)$ \\
\hline
\end{tabular}

decreased protein $\mathrm{C}$ and FVL had a history of pre-eclampsia and two spontaneous abortions; one patient with a blank history showed a positive ANA and anticardiolipin IgG.

None of the patients with a coagulation disorder had a PFO.

\section{Discussion}

The results of the present study demonstrate that conventional cardiovascular risk factors are not only an important risk factor in patients over the age of 50 with ischemic stroke/ TIA, but also in this younger population under the age of 50 .

Almost half of the patients $(47.9 \%)$ had a positive cardiovascular history. Eight of these patients had a history of spontaneous abortions and/or pre-eclampsia. Also the family history for cardiovascular disease was frequently positive $(44.4 \%)$. In the Netherlands, $28 \%$ of the general population was smoking at that time [36], in our population $40 \%$ was smoking. The results of the lipids and glucose values are difficult to compare with results from the literature because of different cut-off values.

$58.8 \%$ of our population was of the female gender. This is comparable with the literature [37]. The higher proportion of women is possibly due to the nature of risk factors for stroke/TIA at younger age; like pregnancy, migraine en oral contraceptives use. These risk factors tend to occur more frequently in women.

We found a history of migraine in $20.2 \%$ of the population. This is analogous to the results of Milhaud et al. [19]. They found migraine in $29.3 \%$ of their population, which was younger $(<35$ years). Furthermore they found $18.2 \%$ of the patients with migraine $(<45$ years) having a PFO. This is analogous to our results (15.8\%). Of all women in our study $42.9 \%$ used oral contraceptives. This is comparable to the Dutch population between 20 and 45 years old $(41 \%)$ [38].

In contrast to what is known from literature, a small number of cardiac anomalies was detected by echocardiography. Kittner [3] and Rodes-Cabau et al. [33] described cardiogenic emboli as the most common cause of ischemic stroke in younger persons (15.4\%). PFO and atrial septal aneuryms (ASA) are described in literature as the most common cardiac anomaly found in stroke/TIA [28-32]. Cabanes et al. [28] distinguished PFO in $43 \%$ and ASA in $28 \%$ of the population $<55$ years old. In our study PFO was detected in only $6.4 \%$ and ASA in $1.3 \%$ of the patients. This discrepancy can be explained by the difference in technique of echocardiography. Cabanes et al. [28] usedlike most of the other investigators [29-32] - transesophageal echocardiography (TEE), instead of TTE. It is suggested that the transesophageal technique is more sensitive in detecting interatrial septum anomalies (PFO, ASA, atrial septal defect), atrial thrombi during atrial fibrillation and mitral valve vegetations like endocarditis [35].

Most of the abnormalities found in thrombophilia- and auto-immune investigations, were detected in patients already known with diseases associated with an increased coagulation before the stroke occurred. Furthermore all patients with decreased protein $\mathrm{C}$ and $\mathrm{S}$ used oral contraception, which is a known cause of decreased protein $\mathrm{C}$ and S [18].

Hankey et al. [8] demonstrated no significant differences between patients with young stroke and controls for protein 
Table 3 Disorders associated with increased blood coagulation/vasculitis

\begin{tabular}{lll}
\hline & $n$ & Comment \\
\hline Systemic lupus erythematosus & 2 & $\begin{array}{c}\text { 1 with positive ANA and lupus anticoagulant; one with positive ANA, } \\
\text { FVL and factor II mutation }\end{array}$ \\
Colitis ulcerosa & 2 & 1 with positive ANA; one with positive ANCA \\
M. Crohn & 2 & 1 with FVL; one with decreased PC and AT \\
Systemic malignancy & 2 & 1 with Non-Hodgkin lymphoma; one with Hodgkin lymphoma \\
Rheumatoid arthritis & 1 & Positive ANA \\
Syndrome of Sneddon & 1 & Positive ANCA \\
Moya Moya syndrome & 1 & \\
Henoch-Schönlein & 1 & \\
Discoid lupus erythematosus & 1 & FVL \\
M. Buerger & 1 & Positive ANA \\
Anti-Jo-1-antibodies syndrome & 1 & a \\
Thrombotic thrombocytopenic purpura & 1 & \\
Polycythaemia vera & 1 & $17(17.5 \%)$
\end{tabular}

$A N A$ anti-nuclear antibodies, $F V L$ factor V Leiden, $A N C A$ anti-neutrophil cytoplasmic antibodies, $P C$ protein $\mathrm{C}, A T$ antithrombin

${ }^{\text {a }}$ Two patients were not screened for thrombophilia and auto-immune disorders

C, S and antithrombin levels. Amiri et al. [9] did not find decreased levels of protein $\mathrm{C}$ and antithrombin at all. The percentages of protein $\mathrm{C}$ and $\mathrm{S}$ that Hankey et al detected are in the range with the percentages we found, except for the antithrombin level. We found a decreased antithrombin level in only $1.2 \%$ of the patients compared to $5.2 \%$ of Amiri et al.

The percentage of our patients with FVL and factor II mutations (7.1 and 3.6\%) is in accordance with the results of the literature $[8,10,14-16]$; none of these studies reported significant differences between patients and controls, or just a minimal increased risk. It has to be noted that positive trombophilia screening has no practical consequences for the patient. There is no difference in kind and duration of anticoagulant treatment between patients with or without a thrombophilic factor.

The homocysteine level was increased in 11 patients. Nowadays it is questionable whether it is still useful to investigate homocysteine levels, since large placebo-controlled trials are published concerning the effect of treating hyperhomocysteinemia [39-42]. Patients (with hyperhomocysteinemia) in these studies had a positive vascular history or a myocardial infarction. Vitamin supplementation caused no significant decrease of recurrence hazard of cardiovascular events. Only Saposnik et al. [43] concluded that vitamin supplementation reduces the risk of overall stroke (ischemic and haemorrhagic), but not stroke severity or disability in a population with and without history of cerebrovascular disease.

In our population a few patients with positive antiphospholipid antibodies were found (1.2\%). Brey et al. [24] found a prevalence of $26.9 \%$ of antiphospholipid antibodies and a prevalence of $14 \%$ of anticardiolipin $\operatorname{IgG}$ and $0.6 \%$ of anticardiolipin IgM. Difference with our population is the fact they only measured all antibodies once, without the corroboration of a second measurement. The patients in our population had a positive test result repeatedly. Munts et al. [2] found a confirmed prevalence of anticardiolipin IgG of $17 \%$. Nencini et al. [25] found prevalences of 18,9 and $7 \%$ for antiphospholipid antibodies, anticardiolipin IgG and IgM.

Urbanus et al. [26] found lupus anticoagulant to be a significant risk factor (OR 43.1) for arterial thrombotic event in women under age 50. Antiphospholipid antibodies were present in $17 \%$ of the patients. The APASS investigators [27] concluded that the presence of antiphospholipid antibodies does not predict an increased risk for subsequent vascular occlusive events in patients with a non-cardiogenic stroke. And thereby may not offer enough value for decisions on therapy.

In contrast to the literature $[29,30]$ we did not identify a combination of thrombophilia and PFO in our population. This can be caused by a low prevalence of both parameters in our population. Furthermore the size of our population is too small to demonstrate an association. Belvís [31] and Florez et al. [34] did not find a significant association between patients with and without PFO for coagulation disorders.

A limitation of this study is that it is retrospective, resulting in incomplete data. Strength of the study is that we investigated many possible risk factors for ischemic stroke in one study. Many studies investigated just one or 
few risk factors in relation to ischemic stroke. Additional prospective, controlled studies of ischemic stroke/TIA patients under age 50 are needed to better assess the roles of the risk factors in the etiology of ischemic stroke/TIA. A relation between migraine and stroke should be corroborated by further studies.

\section{Conclusion and recommendations}

Screening for conventional cardiovascular risk factors remains the most important considering the high percentage of cardiovascular risk factors in patients under age 50. These high frequencies also indicate optimal secondary prevention strategies.

Based on the low laboratory yield of thrombophilia- and auto-immune search, it is not indicated to do this complete laboratory search in all patients under 50, especially not when there is no history related to these diseases. Furthermore in most cases a positive thrombophilic factor has no therapeutic consequences, such as switching of type of anticoagulation or duration of anticoagulation. Thrombophilia and auto-immune research is only indicated in specific cases.

Because of the low number of abnormalities found in TTE, TEE seems preferable instead. Disadvantage of the transesophageal technique is its more invasive nature.

Diagnosis ischemic stroke/TIA

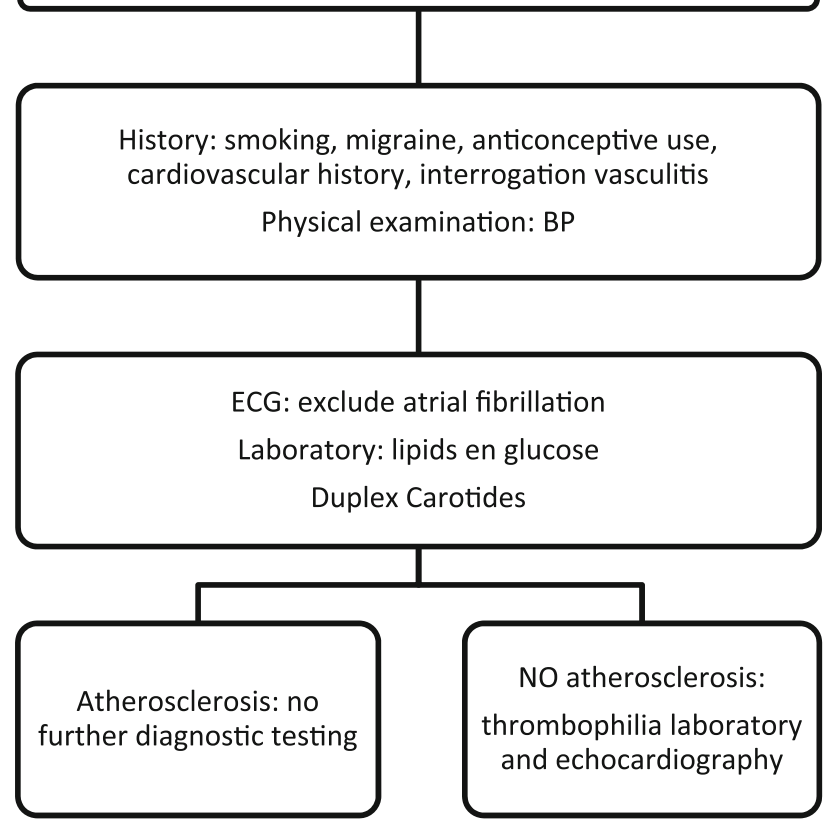

Fig. 1 Recommendation for diagnostic testing in patients with young stroke
Another possibility is the use of TEE in selected young patients, without other risk factors for ischemic stroke.

The ECG should be used to exclude atrial fibrillation. It is cheap and simple.

The use of duplex ultrasound of the extra cranial arteries should be continued. It is a non-invasive test and gives information about the presence of atherosclerosis or dissection in the carotid arteries. Is has a sensitivity of $86 \%$ and specificity of $87 \%$ [44].

History taking remains important in detecting risk factors. Characteristics of auto-immune diseases could be specifically interrogated.

The recommendation for diagnostic testing for possible etiologies and risk factors of ischemic stroke or transient ischemic attack in patients under age 50 is summarized in Fig. 1. The suggested scheme developed on the basis of the results of this study should be further validated in prospective studies.

Sources of Funding Dr De Leeuw received a personal fellowship of the Dutch Brain foundation (H04-12) and a clinical fellowship of the Netherlands Organization for Scientific Research (Project Number: 40-00703-97-07197).

Open Access This article is distributed under the terms of the Creative Commons Attribution Noncommercial License which permits any noncommercial use, distribution, and reproduction in any medium, provided the original author(s) and source are credited.

\section{References}

1. Poos MJJC, van der Wilk EA. Sterfte naar doodsoorzaak samengevat. Volksgezondheid Toekomst Verkenning, Nationaal Kompas Volksgezondheid. www.nationaalkompas.nl. Gezondheid en ziektel Sterfte, levensverwachting en DALY's\Sterfte naar doodsoorzaa. December 2008

2. Munts AG, van Genderen PJ, Dippel DW, van Kooten F, Koudstaal PJ (1998) Coagulation disorders in young adults with acute cerebral ischaemia. J Neurol 245:21-25

3. Kittner SJ, Stern BJ, Wozniak M, Buchholz DW, Earley CJ, Feeser BR, Johnson CJ, Macko RF, McCarter RJ, Price TR, Sherwin R, Sloan MA, Wityk RJ (1998) Cerebral infarction in young adults, the Baltimore-Washington cooperative young stroke study. Neurology 50:890-894

4. Leys D, Bandu L, Henon H, Lucas C, Mounier-Vehier F, Rondepierre P, Godefroy O (2002) Clinical outcome in 287 consecutive young adults (15 tot 45 years) with ischemic stroke. Neurology 59:26-33

5. Goldstein LB, Adams R, Alberts MJ, Appel LJ, Brass LM, Bushnell CD, Culebras A, DeGraba TJ, Gorelick PB, Guyton JR, Hart RG, Howard G, Kelly-Hayes M, Nixon JV, Sacco RL (2006) Primary prevention of ischemic stroke. Stroke 37:1583-1633

6. Putaala J, Metso AJ, Metso TM, Konkola N, Kraemer Y, Haapaniemi E, Kaste M, Taklisumak T (2009) Analysis of 1008 consecutive patients aged 15 to 49 with firts-ever ischemic stroke. The Helsinki young stroke registry. Stroke 40:1195-1203

7. Rahemtullah A, van Cott EM (2007) Hypercoagulation testing in ischemic stroke. Arch Pathol Lab Med 131:890-901 
8. Hankey GJ, Eikelboom JW, van Bockxmeer FM, Lofthouse E, Staples N, Baker RI (2001) Inherited thrombophilia in ischemic stroke and its pathogenic subtypes. Stroke 32:1793-1799

9. Amiri M, Schmidley JW, Fink LM, Nazarian SM (2000) Is testing for inherited coagulation inhibitor deficiencies in young stroke patients worth wile? Clin Neurol Neurosurg 102:219-222

10. Aznar J, Mira Y, Vayá A, Corella D, Ferrando F, Villa P, Estellés A (2004) Factor V Leiden and prothrombin G20210A mutations in young adults with cryptogenic ischemic stroke. Thromb Haemost 91:1031-1034

11. Wu AHB, Tsongalis GJ (2001) Correlation of polymorphisms to coagulation, bichemical risk factors for cardiovascular diseases. Am J Cardiol 87:1361-1366

12. Kim RJ, Becker RC (2003) Association between factor V Leiden, prothrombin G20210A, and methylenetetrahydrofoloate reductase C677T mutations and events of the arterial circulatory system: a meta-analysis of published studies. Am Heart J 146: 948-957

13. Casas JP, Hingorani AD, Bautista LE, Sharma P (2004) Metaanalysis of genetic studies in ischemic stroke. Arch Neurol 61:1652-1662

14. Madonna P, de Stefano V, Coppola A, Cirillo F, Cerbone AM, Orefice G, Di Minno G (2002) Hyperhomocysteinemia and other inherited prothrombotic conditions in young adults with a history of ischemic stroke. Stroke 33:51-56

15. Longstreth WT Jr, Rosendaal FR, Siscovick DS, Vos HL, Schwartz SM, Psaty BM, Raghunathan TE, Koepsell TD, Reitsma PH (1998) Risk of stroke in young women and two prothrombotic mutations: factor $\mathrm{V}$ Leiden and prothrombin gene variant (G20210A). Stroke 29:577-580

16. Zunker P, Hohenstein C, Plendl HJ, Zeller JA, Caso V, Georgiadis D, Allardt A, Deuschl G (2001) Activated protein C resistance and acute ischemic stroke: relation to stroke causation and age. J Neurol 248:701-704

17. Møller J, Nielsen GM, Tvedegaard KC, Andersen NT, Jørgensen PE (2000) A meta-analysis of cerebrovascular disease and hyperhomocysteinaemia. Scand J Clin Lab Invest 60:491-500

18. Bushnell CD, Goldstein LB (2000) Diagnostic testing for coagulopathies in patients with ischemic stroke. Stroke 31:3067-3078

19. Milhaud D, Bogousslavsky J, van Melle G, Liot P (2001) Ischemic stroke, active migraine. Neurology 57:1805-1811

20. Moschiano F, D’Amico D, Ciusani E, Erba N, Rigamonti A, Schieroni F, Bussone G (2004) Coagulation abnormalities in migraine and ischaemic cerebrovascular disease: a link between migraine and ischemic stroke? Neurol Sci 25:S126-S128

21. Etminan M, Takkouche B, Caamaño Isorna F, Samii A (2005) Risk of ischaemic stroke in people with migraine: systemic review and meta-analysis of observational studies. BMJ 330:63

22. Chang CL, Donahy M, Poulter N (1999) Migraine, stroke in young women: case-control study. BMJ 318:13-18

23. Ahmed E, Stegmayr B, Trifunovic J, Weinehall L, Hallmans G, Lefvert AK (2000) Anticardiolipin antibodies are not an independent risk factor for stroke: an incident case-referent study nested within the MONICA and Vasterbotten cohort project. Stroke 31:1289-1293

24. Brey RL, Stallworth CL, McGlasson DL, Wozniak MA, Wityk RJ, Stern BJ, Sloan MA, Sherwin R, Price TR, Macko RF, Johnson CJ, Earley CJ, Buchholz DW, Hebel JR, Kittner SJ (2002) Antiphospholipid antibodies and stroke in young women. Stroke 33:2396-2401

25. Nencini P, Baruffi MC, Abbate R, Massai G, Amaducci L, Inzitari D (1992) Lupus anticoagulant and anticardiolipin antibodies in young adults with cerebral ischemia. Stroke 23:189-193

26. Urbanus RT, Siegerink B, Roest M, Rosendaal MR, de Groot PG, Algra A (2009) Antiphospholipid antibodies and risk of myocardial infarction and ischaemic stroke in young women in the RATIO study: a case-control study. Lancet Neurol 8:998-1005

27. Antiphospholipid antibodies and subsequent thrombo-occlusive events in patients with ischemic stroke. Committee, The APASS Writing (2004) JAMA 291:576-584

28. Cabanes L, Mas JL, Cohen A, Amarenco P, Cabanes PA, Oubary P, Chendru F, Guerin F, Bousser MG, de Recondo J (1993) Atrial septum aneurysm and patent foramen ovale as risk factors for cryptogenic stroke in patients less than 55 years of age. A study using transesophageal echocardiography. Stroke 24:1865-1873

29. Botto N, Spadoni I, Giusti S, Ait-Ali L, Sicari R, Andreassi MG (2007) Prothrombotic mutations as risk factor for cryptogenic ischemic cerebrovascular events in young subjects with patent foramen ovale. Stroke 38:2070-2073

30. Karttunen V, Hiltunen L, Rasi V, Vahtera E, Hillbom M (2003) Factor $\mathrm{V}$ Leiden and prothrombin gene mutation may predispose to paradoxical embolism in subjects with patent foramen ovale. Blood Coagul Fibrinolysis 14:261-268

31. Belvís R, Santamaría A, Martí-Fàbregas J, Leta RG, Cocho D, Borrell M, Fontcuberta J, Martí-Vilalta JL (2007) Patent foramen ovale and prothrombotic markers in young stroke patients. Blood Coagul Fibrinolysis 18:537-542

32. Offelli P, Zanchetta M, Pedon L, Marzot F, Cucchini U, Pegoraro C, Iliceto S, Pengo V (2007) Thrombophilia in young patients with cryptogenic stroke and patent foramen ovale (PFO). Thromb Haemost 98:906-907

33. Rodés-Cabau J, Noël M, Marrero A, Rivest D, Mackey A, Houde C, Bédard E, Larose E, Verreault S, Peticlerc M, Pibarot P, Bogaty P, Bertrand OF (2009) Athersclerotic burden findings in young cryptogenic stroke patients with and without a patent foramen ovale. Stroke 40:419-425

34. Florez JC, Ay H, van Cott EM, Buonanno FS (2003) Patent foramen ovale and hypercoagulability as combined risk factors for stroke. J Stroke Cerebrovasc Dis 339:589-594

35. Hart RG (1992) Cardiogenic embolism to the brain. Lancet 339:589-594

36. STIVORO. http://www.stivoro.nl/Voor_professionals/Feiten_Cijfers/ Actuele_gegevens_over_roken/Index.aspx?mId=9929\&rId-299

37. Sacco RL, Boden-Albala B, Gan R, Chen X, Kargman DE (1998) Stroke incidence among white. black, and hispanic residents of an urban community. Am J Epidemiol 147:259-268

38. de Graaf A. http://www.cbs.nl/nl-NL/menu/themas/bevolking/ publicaties/artikelen/archief/2004/2004-1389-wm.htm

39. Lonn $\mathrm{E}$ (2007) Homocysteine in the prevention of ischemic heart disease, stroke, venous thromboembolism: therapeutic target or just another distraction? Curr Opin Hematol 14:481-487

40. Lonn E, Yusuf S, Phil D, Arnold MJ, Sheridan P, Pogue J, Micks M, McQueen MJ, Probstfield J, Fodor G, Held C, Genest J (2006) Homocysteine lowering with folic acid and B vitamins in vascular disease. N Engl J Med 354:1567-1577

41. Bønaa KH, Njølstad I, Ueland PM, Schirmer H, Tverdal A, Steigen T, Wang H, Nordrehaug JE, Arnesen J, Rasmussen K (2006) Homocysteine lowering and cardiovascular events after acute myocardial infarction. N Engl J Med 354:1578-1588

42. Bazzano LA, Reynolds K, Holder KN, He J (2006) Folic acid supplementation on risk of cardiovascular diseases: a metaanalysis of randomized controlled trial. JAMA 296:2720-2726

43. Saposnik G, Ray JG, Sheridan P, McQueen M, Lonn E (2009) Homocysteine-lowering therapy and stroke risk. Severity, and disability; additional findings from the HOPE 2 trial. Stroke 40:1365-1372

44. Nederkroon PJ, van der Graaf Y, Hunink MG (2003) Duplex ultrasound and magnetic resonance angiography compared with digital subtraction angiography in carotid artery stenosis: a systemic review. Stroke 34:1324-1332 